\title{
Post-embriononic development of Chrysomya putoria (Diptera: Calliphoridae) on a diet containing ampicillin in different concentrations
}

\author{
ADRIANA C.P. FERRAZ ${ }^{1}$, DANIELE L. DALLAVECCHIA ${ }^{1,2}$, DÉBORA C. \\ SILVA $^{3}$, RENATO G. SILVA-FILHO ${ }^{1}$ and VALÉRIA M. AGUIAR ${ }^{1,2}$ \\ ${ }^{1}$ Universidade Federal do Estado do Rio de Janeiro, Departamento de Microbiologia e Parasitologia, \\ Laboratório de Estudo de Dípteros, Rua Frei Caneca, 94, Centro, 20211-040 Rio de Janeiro, RJ, Brasil \\ ${ }^{2}$ Programa de Pós-Graduação em Ciências Biológicas (Biodiversidade Neotropical), Universidade Federal \\ do Estado do Rio de Janeiro, Av. Pasteur, 296, Urca, 22290-240 Rio de Janeiro, RJ, Brasil \\ ${ }^{3}$ Universidade Estadual do Sudoeste da Bahia, Departamento de Estudos Básicos e Instrumentais, \\ Estrada do Bem Querer, Km 04, 45083-900 Vitória da Conquista, BA, Brasil
}

Manuscript received on September 1, 2014; accepted for publication on January 16, 2015

\begin{abstract}
Here we evaluate the effects of different concentrations of the antibiotic ampicillin on the growth and development of Chrysomya putoria. Third-generation, first instar larvae (L1) reared on 60 grams of homogenate+agar $65 \%$ were treated with ampicillin sodium. The experiment consisted of four replicates (40 larvae/replicate) of each antibiotic concentration tested (T1: $466 \mu \mathrm{g} / \mathrm{mL} ; \mathrm{T} 2: 81.33 \mathrm{mg} / \mathrm{mL}$ and T3: $166.66 \mathrm{mg} / \mathrm{mL}$ ) and a T4: control. The body mass of the mature larvae, after they abandoned the diet, were recorded in batches of five. The variation between the mean body mass of larvae and the duration of larval and pupal stages, and overall duration of the development, viability and normal rates were analyzed by ANOVA. There were no significant differences between the four treatments in the following parameters: body mass of larvae that discontinued the diet as well as the duration of larval, pupal, and total development. The sex ratios found in the four treatments did not differ from those expected. Normality rates were $100 \%$ for all treatments. There were no significant differences between treatments for larval and overall viability, but pupal viability differed significantly between $\mathrm{T} 1$ and the control, $\mathrm{T} 1$ and $\mathrm{T} 2$, and between the control and T3. The antibiotic did not appear to significantly alter the development of C. putoria.
\end{abstract}

Key words: Ampicillin, biology, bowfly, Callihoridae, forensic entomology.

\section{INTRODUCTION}

Antibiotics are considered a universal panacea. They account for $12 \%$ of all outpatient prescriptions, however two thirds of all antibiotics are sold without a prescription (Wannmacher 2004). For some time, antibiotics have been the most widely

Correspondence to: Valéria Magalhães Aguiar

E-mail: valeria@unirio.br / valerialed@yahoo.com.br used pharmaceutical group in self-medication (Mestanza and Pamo 1992).

Penicillins are the antibiotics of choice to treat a number of pathologies. Ampicillin is indicated for the treatment of various infections that are caused by gram - positive and gram-negative bacteria: infections of the urinary, respiratory, and digestive tracts, as well as gall infections, localized 
or systemic infections and infections of the mouth, caused by teeth extractions and other surgical procedures (Porto 2012, Tavares 2014).

Many substances as drugs, or their metabolites, can affect the development of arthropods of forensic importance when present in the cadavers that they colonize (Introna et al. 2001). Substances such as scopolamine, buscopan, malathion, diazepam and methadone decrease the development rate of insects (Carvalho et al. 2001, 2012, Grella et al. 2007, Liu et al. 2009, Gosselin et al. 2011). In addition, increased larval development was observed when insects were exposed to heroin, methamphetamine, codeine and paracetamol (Goff et al. 1991, Carvalho et al. 2004, O`Brien and Turner 2004). However, the effect of penicillin on insect development remains unknown.

Insects can even be used as an alternative method for the detection of toxic substances because they do not always metabolize the drugs they ingest, leaving traces that can be detected long after the death of an organism (Hédouin et al. 1999, Introna et al. 2001, Carvalho et al. 2001, El-bar and Sawaby 2011).

Insects of forensic importance such as blow flies are used to estimate the post mortem interval (IPM) in legal investigations where the time of death is greater than $72 \mathrm{~h}$ and the temperature of the cadaver can no longer be used for such estimates. The post mortem interval is determined by collecting immature larvae from the body which allows the insect to be identified, along with its size and stage (Parry et al. 2011). Flies of the Calliphoridae family should be considered for the calculation of the post-mortem interval (PMI) (Vanlaerhoven 2008). In particular, Chrysomya species should be considered because they are the first invaders of carcasses, playing an important role in the sciences (El-bar and Sawaby 2011, Oliveira-Costa 2011, Oliveira and Vasconcelos 2010). Ignoring toxicological analyses when calculating PMI can lead to erroneous estimates because certain substances ingested before death can alter the rate of development of some species of flies that feed on cadaver tissues (Gosselin et al. 2011).

Chysomya putoria has rapid dispersion and rapid larval development (Oliveira et al. 2007, Ferraz et al. 2011a, 2012). It was originally found in Africa, the Mediterranean and the Middle East and was introduced in Brazil in the 1970s. In addition, it has high synanthropy and can be found in several biotopes, including rural, urban and anthropic forest environments (Ferraz et al. 2009, Batista-da-Silva et al. 2010, Kosmann et al. 2013, Cabrini et al. 2013). This species has been reported to cause secondary myiasis in animals and humans (Guimaraes and Pavavero 1999). It also plays a role as a mechanical vector of pathogenic organisms (Furlanetto et al. 1984) because of its habit of breeding in decomposing organic matter. C. putoria is also known for its potential use in larval therapy, which is a technique that uses fly larvae to remove necrotic tissue and assist in wound healing (Dallavecchia et al. 2011). An antibiotic treatment, including penicillin therapy, cannot be interrupted in some patients, however, they can also undergo larval therapy simultaneously. Worldwide, doctors have suggested larval therapy as the firstline treatment for the meticulous removal of dead tissue, particularly in diabetic patients. As of the 1990s, the Food and Drug Administration (FDA) has approved the medicinal use of larvae as an effective treatment for the removal of devitalised tissue in poorly healing wounds (Dallavecchia et al. 2014).

The species of Calliphoridae can feed on human tissues during their larval stage, either on dead tissues, (participating in the process of corpse decomposition), on live tissues, (causing myiasis) or during larval therapy. Thus, these species can absorb drugs from host tissues, which can lead to changes in their development rate. Considering patients who undergo an antibiotic regimen or cases of overuse of antibiotics, and the fact that we know little about how and for how long fly 
larvae accumulate these drugs in their system, how they eliminate them and how drugs affect their development (Soto 2008), we endeavored to investigate the effects of ampicillin on the postembryonic development of Chrysomya putoria (Wiedemann, 1830).

\section{MATERIALS AND METHODS}

Flies were reared and all the experiments were conducted at the Laboratory for the Study of Diptera (LED), Department of Microbiology and Parasitology, Universidade Federal do Estado do Rio de Janeiro (UNIRIO).

Adult blowflies (C. putoria) were obtained from a stock colony originated from insects collected at the Rio de Janeiro Zoo, which is located at the Quinta da Boa Vista Park, São Cristóvão, RJ. We used three traps following the model of Mello et al. (2007), containing sardine as bait. Traps remained exposed for about five hours in the morning. After being collected, adults and larvae of muscoid flies were taken to the LED where they were sorted and identified as per Mello (2003). The flies were reared in plastic cages $(40 \times 30 \times 20 \mathrm{~cm})$ with an opening at the top for aeration and an anterior opening to allow access to the inside of the cage, which was covered with escaline coated fabric. The flies were offered water, honey and water (50\%) solution, and chicken gizzard or beef as a protein source, substrate for oviposition and ovary maturation. The rearing methodology followed Barbosa et al. (2004) and Ferraz et al. (2011a).

First-instar larvae of the $3^{\text {rd }}$ laboratory generation were transferred with the help of a fine paintbrush to $100 \mathrm{~mL}$ beakers containing $60 \mathrm{~g}$ gizzard/agar $65 \%$ homogenate (Ferraz et al. 2012). This diet was selected because it is practical and sterile (autoclaved), allowing the antibiotic to act fully and only on the larvae. We used $1 \mathrm{~g}$ of the antibiotic generic ampicillin sodium (Teuto Lab). Each repetition received $1 \mathrm{~mL}$ of the antibiotic, resulting in the following three final concentrations in the food: $41.66 \mathrm{mg} / \mathrm{mL}, 81.33 \mathrm{mg} / \mathrm{mL}$ and 166.66 $\mathrm{mg} / \mathrm{mL}$. The concentrations were chosen from the serum ampicillin concentration (after intravenous dose of $1 \mathrm{~g}$, the maximum concentration of approximately $40 \mu \mathrm{g} / \mathrm{mL}$ is reached) (Ampicillin 2011). The first concentration chosen (T1) is close to the intravenous serum concentration; the second (T2) is close to the maximum intravenous serum concentration; the third (T3) is approximately four times the maximum serum intravenous concentration. Each antibiotic concentration tested, and the control, were replicated four times using 40 larvae in each repetition. The control received distilled water instead of the antibiotic.

Dilutions of a commercial injectable ampicillin (ampicillin sodium $1 \mathrm{~g}$; Teuto Lab) were prepared in water for injectable preparations, and $1 \mathrm{~mL}$ aliquots were added to the feed to obtain final concentrations of $41.6,81.33$ and $166.66 \mu \mathrm{g} / \mathrm{g}$. The concentration of the antibiotic in the feed was based on the value of the serum concentration after the intravenous injection of $1 \mathrm{~g}$ (approximately $40 \mu \mathrm{g} / \mathrm{mL}$ ).

Each beaker was put into a larger beaker (400 $\mathrm{mL}$ ) containing sterilized sawdust and was sealed with elastic escaline. The sawdust was provided in order to allow the larvae to pupate after abandoning the diet. The larvae were kept in a climatic chamber at $30{ }^{\circ} \mathrm{C} /$ day and $28{ }^{\circ} \mathrm{C} /$ night, $70 \pm 10 \% \mathrm{RH}$ and $14 \mathrm{~h}$ photoperiod. Observations were made daily, always at the same time (12 h).

The body mass of larvae that abandoned the diet was recorded in batches of five with the help of an analytical scale. Larvae were then stored in test tubes sealed with nylon and elastic fabric for further observations. We recorded the dates of pupation and emergence, as well as the sex ratio and morphological abnormalities of the adults, when present.

The following variables were evaluated: body mass of larvae that discontinued the diet; duration of post-embryonic development from larval hatching to the interruption of the diet (period from the inoculation of L1 in the diet 
until the development of third instar larvae, which tend to abandon the diet in favour of the pupation substrate); larval stage (the period between the interruption of diet until pupal formation); pupal stage (from pupae until the emergence of adults) and total duration (from L1 to the emergence of adults). The frequency of interruption of the larval diet, pupation and emergence of adults as well as the frequency of male and female emergences was graphically demonstrated. We also showed larval, pupal and total viability, gender ratio and percentage of normal insects (i.e. those with no visible morphological deformities such as lack of distention of the wings, visible reduction of body size, wrinkled cuticles, sharp increase in the head size and retracted pitilinum).
We used the program Microsoft Excel to analyze the raw data and other analyses were conducted in the program PAST. Variations in the mean body mass of larvae, the duration of the stages of postembryonic development and the viability and normal rates were compared by ANOVA ( $5 \%$ significance). The observed sex ratio was tested against the expected frequency, using chi-square $\left(\chi^{2}\right)$.

\section{RESULTS}

The four treatments did not differ significantly with respect to the body mass of C. putoria larvae (Table I). Furthermore, the average duration from L1 until the discontinuation of the diet, larval, pupal and total (days) stages did not differ significantly among the four treatments (Table II).

TABLE I

Body mass of larvae (g)* of the blowfly Chrysomya putoria (Wiedemann, 1830) (Diptera, Calliphoridae) after four treatments with different concentrations of ampicillin, reared in a climatic chamber $\left(30{ }^{\circ} \mathrm{C}\right.$ day and $28^{\circ} \mathrm{C}$ night, $70+10 \% \mathrm{RH}$ and $14 \mathrm{~h}$ photoperiod).

\begin{tabular}{lll}
\hline Treatment & $\begin{array}{l}\text { Mean individual mass }(\mathrm{g}) \pm \\
\text { Standard deviation }\end{array}$ & Variation interval \\
Control & $0.039 \mathrm{a} \pm 0.015$ & $0.014-0.059$ \\
\hline T1 & $0.038 \mathrm{a} \pm 0.012$ & $0.012-0.058$ \\
T2 & $0.049 \mathrm{a} \pm 0.008$ & $0.016-0.062$ \\
T3 & $0.046 \mathrm{a} \pm 0.005$ & $0.031-0.056$ \\
\hline
\end{tabular}

* Means followed by same letter in same column do not differ significantly by ANOVA, $5 \%$ confidence.

control $=$ gizzard homogenate agar; $\mathrm{T} 1=$ gizzard homogenate agar + ampicillin $41.66 \mu \mathrm{g} / \mathrm{mL}, \mathrm{T} 2$ = gizzard homogenate agar + ampicillin 81.33 $\mu \mathrm{g} / \mathrm{mL}, \mathrm{T} 3=$ gizzard homogenate agar + ampicillin $166.66 \mu \mathrm{g} / \mathrm{mL}$.

TABLE II

Average duration of the post-embryonic development stages *(days) of larvae of the blowfly Chrysomya putoria (Wiedemann, 1830) subjected to four treatments with different concentrations of ampicillin and reared in a climatic chamber (30 ${ }^{\circ} \mathrm{C}$ day and $28^{\circ} \mathrm{C}$ night, $70 \pm 10 \% \mathrm{RH}$ and $14 \mathrm{~h}$ photoperiod).

\begin{tabular}{ccccc}
\hline & Day & $\begin{array}{c}\text { Variation } \\
\text { interval }\end{array}$ & $\begin{array}{c}\text { Standard } \\
\text { Deviation }\end{array}$ \\
\hline & Control & $3.617 \mathrm{a}$ & $3-4$ & 0.466 \\
& $\mathbf{T 1}$ & $3.510 \mathrm{a}$ & $3-4$ & 0.412 \\
\hline
\end{tabular}


TABLE II (continuation)

\begin{tabular}{|c|c|c|c|c|}
\hline & & Day & $\begin{array}{c}\text { Variation } \\
\text { interval }\end{array}$ & $\begin{array}{l}\text { Standard } \\
\text { Deviation }\end{array}$ \\
\hline \multirow{4}{*}{ 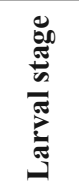 } & Control & $4.617 \mathrm{a}$ & $4-5$ & 0.466 \\
\hline & T1 & $4.016 \mathrm{a}$ & $4-5$ & 0.729 \\
\hline & $\mathbf{T} 2$ & $4.174 \mathrm{a}$ & $4-5$ & 0.174 \\
\hline & T3 & $4.469 \mathrm{a}$ & $4-7$ & 0.700 \\
\hline \multirow{4}{*}{ 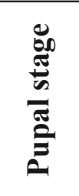 } & Control & $3.660 \mathrm{a}$ & $3-5$ & 0.271 \\
\hline & T1 & $3.664 \mathrm{a}$ & $3-5$ & 0.490 \\
\hline & $\mathbf{T} 2$ & $3.807 \mathrm{a}$ & $3-5$ & 0.170 \\
\hline & T3 & $3.623 \mathrm{a}$ & $3-5$ & 0.420 \\
\hline \multirow{4}{*}{ 党 } & Control & $8.279 a$ & $8-9$ & 0.244 \\
\hline & T1 & $8.183 a$ & $8-9$ & 0.223 \\
\hline & $\mathbf{T} 2$ & $7.888 \mathrm{a}$ & $8-10$ & 0.333 \\
\hline & T3 & $8.218 \mathrm{a}$ & $8-9$ & 0.195 \\
\hline
\end{tabular}

*Means followed by same letter in same column do not differ significantly by ANOVA, $5 \%$ confidence.

Control $=$ gizzard homogenate in agar; $\mathrm{T} 1=$ gizzard homogenate in agar $+41.66 \mu \mathrm{g} /$ $\mathrm{mL}$ ampicillin; $\mathrm{T} 2=$ gizzard homogenate in agar $+81.33 \mu \mathrm{g} / \mathrm{mL}$ ampicilin, $\mathrm{T} 3=$ gizzard homogenate in agar $+166.66 \mu \mathrm{g} / \mathrm{mL}$ ampicillin.

The rates of diet abandonment, pupation and emergence (\%) obtained for C. putoria in the four different treatments are shown in Figure 1. There is very little difference in the peaks of abandonment, pupation and emergence between the four treatments.

The sex ratios were as follows: control (males $=48 \%$, females $=52 \%$ ); T1 (males $=48 \%$, females $=52 \%)$, T2 $($ males $=54 \%$, females $=46$ $\%)$ and $\mathrm{T} 3($ males $=49 \%$ females $=51 \%$ ). The chi-square tests revealed that the sex ratios found in the four treatments did not differ from the expected (control: $\chi^{2}=0.001, \mathrm{~T} 1: \chi^{2}=0.001, \mathrm{~T} 2: \chi^{2}=0.007$, T3: $\chi^{2}=0.001$; tabulated $\chi^{2}=3.84, \mathrm{gl}=1, \alpha=5 \%$ ).

All adults $(100 \%)$ in the control and in the other treatments were normal, i.e., showed no morphological deformities. The rate of emergence of males and females of C. putoria was similar (Fig. 2), the emergence peak of both occurred on the $8^{\text {th }}$ day. Only in T2 and T3 the emergence of females extended up to the $10^{\text {th }}$ day.

As for larval and overall viability, there were no significant differences between the treatments
(Table III). The pupal viability of T1 (lower than in the other treatments) differed significantly from the control and T2, and the pupal viability of T3 differed from the control.

\section{DISCUSSION}

Human myiasis is the presence of fly larvae in human tissues, where they feed and develop as parasites. They preferentially develop in the human skin but frequently reach natural body cavities (Ferraz et al. 2011b). They constitute an important public health problem because of the strong social component associated with their presence. Myiasis can occur in areas previously affected by other illnesses (or dermatoses), including erysipelas, which are treated with penicillin as the first option in most cases (Braga et al. 2011). This pathology is caused by species of the Calliphoridae family, mainly C. putoria, which has scavenger/necrophagic behaviour and develops in dead tissues (corpses) or necrotic wounds of living hosts (Guimaraes and Pavavero 1999). It is known that certain chemicals and hormones exert a deleterious effect on insect 


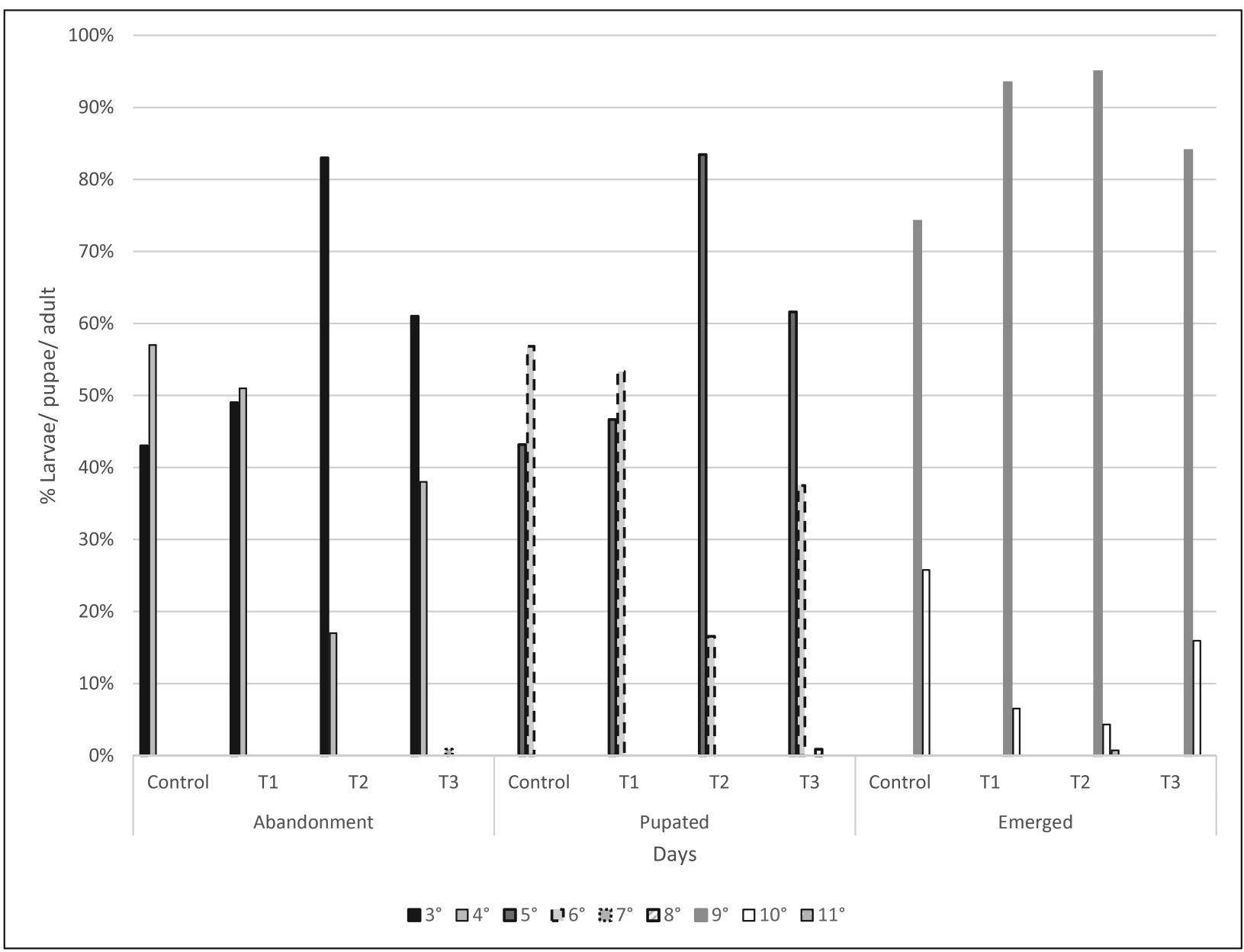

Figure 1 - Rate of diet abandonment, pupation and emergence (\%) of Chrysomya putoria (Wiedemann, 1830) subjected to four treatments: control = gizzard homogenate agar; $\mathrm{T} 1=$ gizzard homogenate agar + ampicillin $41.66 \mu \mathrm{g} / \mathrm{mL}$, T2 = gizzard homogenate agar + ampicillin $81.33 \mu \mathrm{g} / \mathrm{mL}$, T3 = gizzard homogenate agar + ampicillin $166.66 \mu \mathrm{g} / \mathrm{mL}$.

development (Carvalho et al. 2001, 2012, Liu et al. 2009, Gosselin et al. 2011). However, the effect of antibiotics such as ampicillin on the development of fly larvae remains unknown.

Blowfly larvae (Calliphoridae) can be used in larval therapy for treating different types of wounds. These larvae remove the necrotic tissue, stimulate granulation tissue and promote microbial decontamination (Dallavecchia et al. 2011). Lucilia sericata larvae (Meigen, 1826) (Diptera: Calliphoridae) are the most commonly used species in the Northern Hemisphere, whereas in Brazil, Chrysomya species have the potential of being used for larval therapy (Dallavecchia et al.
2011). At present, larval therapy is used in medical procedures in over 30 countries worldwide. On the other hand, strategies for the sterilisation of eggs and disinfection of larvae are still being developed in Brazil (Dallavecchia et al. 2014). Antibiotic therapy is often associated with larval therapy; however, the extent to which antibiotics can affect the development of larvae used for medicinal purposes remains unknown.

Another field of biology in which calliphorid flies are important is forensic entomology, which studies the biology and behaviour of insects and other arthropods during criminal investigations. The most common use of this knowledge is for 


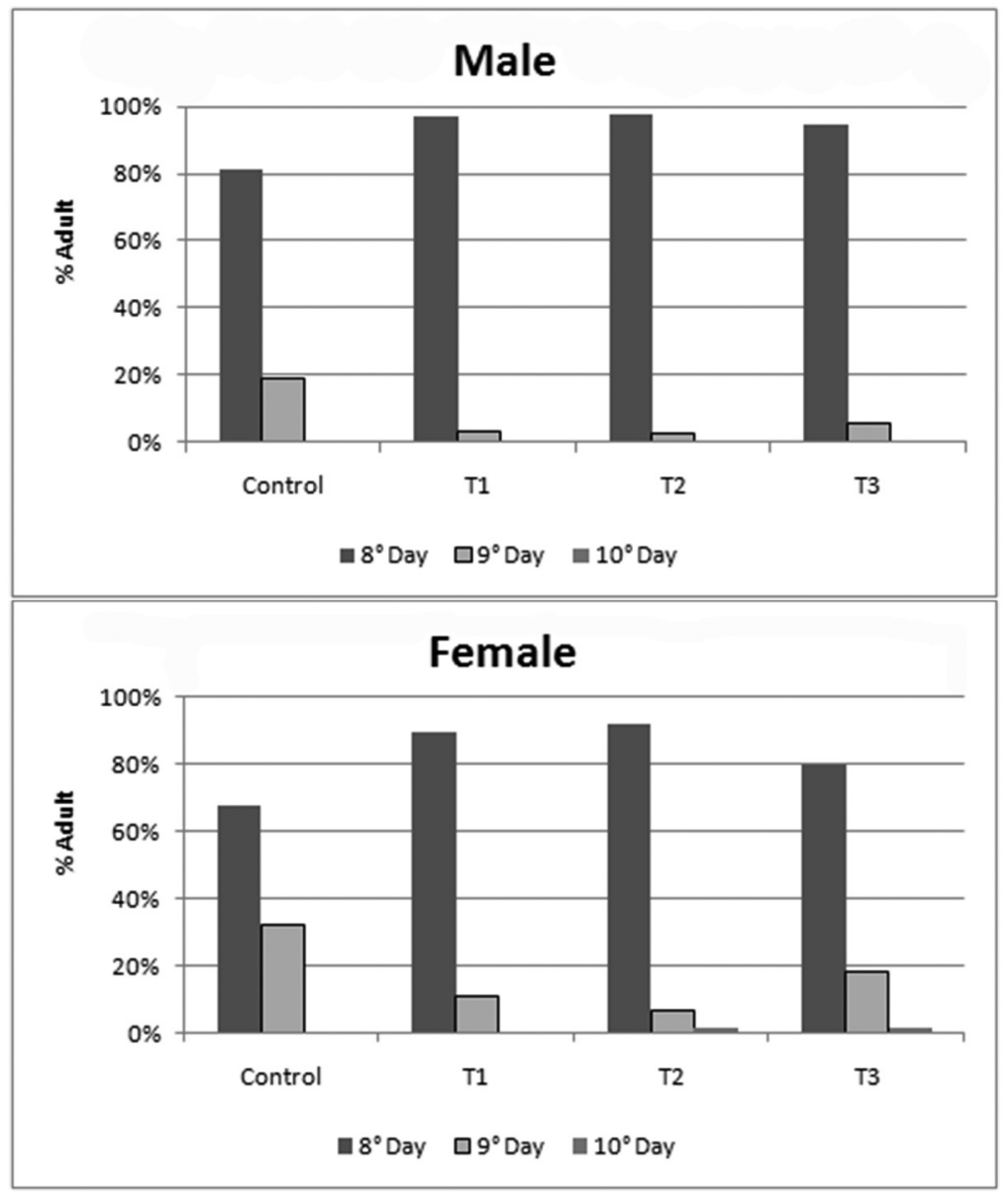

Figure 2 - Rate of emergence, in days, of males and females of Chrysomya putoria (Wiedemann, 1830) subjected to four treatments: control = gizzard homogenate agar; T1 = gizzard homogenate agar + ampicillin $41.66 \mu \mathrm{g} / \mathrm{mL}$, T2 = gizzard homogenate agar + ampicillin $81.33 \mu \mathrm{g} / \mathrm{mL}$, T3 = gizzard homogenate agar + ampicillin $166.66 \mu \mathrm{g} / \mathrm{mL}$.

TABLE III

ANOVA comparison of the viability of larvae, pupae and total (L1 to adult) of Chrysomya putoria (Wiedemann, 1830) subjected to four treatments: control = gizzard homogenate agar; T1 = gizzard homogenate agar + ampicillin $41.66 \mu \mathrm{g} / \mathrm{mL}, \mathrm{T} 2$ = gizzard homogenate agar + ampicillin $81.33 \mu \mathrm{g}$ / $\mathrm{mL}, \mathrm{T3}=$ gizzard homogenate agar + ampicillin $166.66 \mu \mathrm{g} / \mathrm{mL}$.

\begin{tabular}{|c|c|c|c|c|c|c|}
\hline & & \multirow{2}{*}{ Viability*(\%) } & \multicolumn{4}{|c|}{$\boldsymbol{p}=$ significance value (ANOVA) } \\
\hline & & & Control & T1 & $\mathbf{T 2}$ & T3 \\
\hline \multirow{4}{*}{ 苞 } & Control & $82.50 \mathrm{a}$ & - & 0.176 & 0.444 & 0.492 \\
\hline & T1 & $96.88 \mathrm{a}$ & 0.176 & - & 0.162 & 0.113 \\
\hline & $\mathbf{T 2}$ & $90.63 a$ & 0.444 & 0.162 & - & 0.214 \\
\hline & T3 & $70.00 \mathrm{a}$ & 0.492 & 0.113 & 0.214 & - \\
\hline \multirow{4}{*}{$\begin{array}{l}\overline{\tilde{a}} \\
\stackrel{\Xi}{\Xi} \\
\text {. }\end{array}$} & Control & $96.37 \mathrm{a}$ & - & 0.024 & 0.929 & 0.008 \\
\hline & T1 & $78.46 b$ & 0.024 & - & 0.048 & 0.371 \\
\hline & $\mathbf{T} 2$ & $95.95 \mathrm{a}$ & 0.929 & 0.048 & - & 0.056 \\
\hline & T3 & $84.42 b$ & 0.008 & 0.371 & 0.056 & - \\
\hline
\end{tabular}


TABLE III (continuation)

\begin{tabular}{|c|c|c|c|c|c|c|}
\hline & & \multirow{2}{*}{ Viability*(\%) } & \multicolumn{4}{|c|}{$\boldsymbol{p}=$ significance value (ANOVA) } \\
\hline & & & Control & T1 & T2 & T3 \\
\hline \multirow{4}{*}{$\stackrel{\pi}{0}$} & Control & $80.00 \mathrm{a}$ & - & 0.764 & 0.560 & 0.223 \\
\hline & T1 & $76.25 \mathrm{a}$ & 0.764 & - & 0.237 & 0.246 \\
\hline & $\mathbf{T} 2$ & $86.88 \mathrm{a}$ & 0.560 & 0.237 & - & 0.072 \\
\hline & T3 & $58.75 \mathrm{a}$ & 0.223 & 0.246 & 0.072 & - \\
\hline
\end{tabular}

*Means followed by same letter in same column do not differ significantly by ANOVA, $5 \%$ confidence.

determining PMI, which estimates the period for which the body remained at the crime scene and the period of death. By providing an estimates of PMI, particularly between 2 and 4 weeks of decomposition, it is assumed that insects will develop at predictable rates, considering certain environmental conditions. Moreover, the effects of drugs on insect development need to be considered (Oliveira-Costa 2011). Ignoring this data may result in errors in the PMI estimates of up to days (Parry et al. 2011).

Antibiotics are commonly used to cure an established infection and have the effect of hindering or preventing bacterial growth (Porto 2012). Therefore, patients with myiasis, who often have infected wounds, or patients who make use of larval therapy, usually take this type of drug. Considering also that the number of illicit drug users, and users of other toxic substances, have gradually increased over the years, studies on entomotoxicity are important to understand the possible interactions between insects and these substances (Introna et al. 2001, UNODC 2007). When scavenger insects ingest drugs by feeding on the corpses of individuals who used drugs, their rate of development and metabolism may be altered (Introna et al. 2001). We tested the effect of three concentrations of ampicillin on the development of $C$. putoria. The concentrations chosen were similar to serum intravenous concentrations in cases in which individuals were taking ampicillin according to medical recommendations for the treatment of infections; the other concentrations tested corresponded to an overdose of antibiotics, equivalent to concentrations that were two to four times greater than the serum concentration. In the present study, a few parameters were altered by the presence of ampicillin, as will be shown below.

To evaluate the effects of different substances on fly development, many authors have used guinea pig tissues (Carvalho et al. 2001, George et al. 2009, Liu et al. 2009) in addition to natural diet along with the substance to be tested (Grella et al. 2007, Parry et al. 2011). However, artificial diets can be used to homogeneously introduce substances in treatments, dispensing with the need for cobaios, which are expensive to handle (Soto 2008). Similarly, we know the exact composition of artificial diets, and by using them we are able to prevent possible unwanted interactions with the substance to be tested. The artificial diet used in our study allowed the consumption of ampicillin at different concentrations, to observe potential reactions of flies in the presence of this compound in their diet. Moreover, this diet contains few ingredients, which is an advantage when the influence of chemicals on insect development needs to be evaluated. The agar base used in this artificial diet has been used in the formulation of diets for other insect groups, and most of them are with insects of agricultural importance (Parra 2002).

Previous studies have shown that, in calliphorids, adults end up smaller and lighter when there are limitations in space and food during their development. Consequently, the final size of adults 
reflects the quantity and quality of the nutrition consumed during the larval stage (Goodbrod and Goff 1990, Reis et al. 1994). Considering that the body mass of larvae was not significantly different among the four treatments, we can conclude that a decrease in food intake and/or food absorption, even in the presence of antibiotics, did not take place. The diet we provided was rich in proteins and is adequate for calliphorids (Yaghoobi et al. 2005), which seek to ingest as much food as possible before the resources are exhausted. The larvae then disperse in the search for new food sources or a location to pupate (Greenberg 1990), which also happened in the present study when they switched to the larger beaker containing sawdust.

The amount of gizzard homogenate + agar used in the diet in each repetition also secured the ideal relative density of more than $1 \mathrm{~g}$ of meat per larva, as advocated by Aguiar-Coelho and Milward-de-Azevedo (1996) for different calliphorids, as a means to avoid the stress of exploitative competition for resources or chemical changes in the food substrate resulting from the larval metabolism (Khazaeli et al. 1993, Bubli et al. 1998). The amount of food can also alter the phenotype (Ribeiro et al. 1993, Reis et al. 1994, Roper et al. 1996, Ribeiro 1998), but even in the treatments with ampicillin, $100 \%$ of the adults were normal.

Oliveira et al. (2007), in a study using $C$. putoria reared on beef (acclimatized chamber at 27 ${ }^{\circ} \mathrm{C} \pm 1,60 \pm 10 \%$ RH. and 14 photophase), observed that larval development lasts $92 \mathrm{~h}$ (approximately 3.83 days). This is less than the durations obtained in our four treatments. Ferraz et al. (2011a), using beef and dog food at room temperature (average $\max \mathrm{T}=25.0{ }^{\circ} \mathrm{C}$, mean average $\mathrm{T}=21.5^{\circ} \mathrm{C}$, RH 60$90 \%$ ) found higher values. The increase in the time it takes for the larval stage to complete, is a strategy to offset the decline in the nutritional quality of the food consumed (Aguiar-Coelho and Milwardde-Azevedo 1996). However, the differences in the results between the first and second studies and ours did not exceed one day. There were also no significant differences in the duration of larval, pupal, and total development between the control and each of the treatments with ampicillin. Therefore, it is possible that the antibiotic did not affect the conversion of food, i.e. during all treatments, larvae reached similar body weights when feeding on the substrate in the same period.

Larvae in T3, which received the highest antibiotic concentration, took a day longer to abandon the diet, pupate, and emerge than the other treatments. It is possible that the antibiotic changed some organoleptic characteristics of their diet. It has been shown that the behaviour of $C$. albiceps (Diptera: Caliphoridae) larvae is altered by palatability and by pheromones (Faria et al. 2004). The presence of drugs in tissues can affect larval development of scavenger flies that feed on these substrates. In many cases, PMI is calculated by measuring the weight and age of immature larvae collected in a body; therefore, ignoring this interfering factor may lead to an underestimation of the time of death (up to $48 \mathrm{~h}$ ) (Thyssen and Grella 2011).

Nevertheless, the population of flies that emerged from all treatments can be considered stable, since none diverged from the expected sex ratio $1: 1$ and the rate of emergence of males and females was also similar (only in $\mathrm{T} 2$ and $\mathrm{T} 3$ the emergence of females extended up to one day longer). Viability was also above $60 \%$ in all treatments, except for total viability in T3. This value is considered promising in Diptera (Loureiro et al. 2005) for laboratory studies with diets. Despite the decreased viability of flies that fed on the diet with the highest antibiotic concentration, on average, $60 \%$ of the immature stages developed into the adult stage; therefore, this decrease was not significant.

Some authors believe that there is a correlation between the concentration of drugs present in the 
tissues eaten by larvae, and the concentration of the same drugs in the larval tissues (Introna Jr et al. 1990, Kintz et al. 1990). Other authors, by contrast, indicate that no such relationship exists, because the process of accumulation and elimination of substances by the larvae may vary according to the drug and the species analyzed (Sadler et al. 1997). In skeletonised bodies or those at an advanced stage of decomposition, where traditional sources of analysis such as blood, urine or internal organs are not available, insects may serve as reliable sources for toxicological analyses. In addition, insects are used in the detection of licit or illicit drugs present in the body, including stimulants, CNS depressants, anti-depressants, analgesics, amphetamines and cocaine. Entomotoxicological studies should primarily focus on drug bioaccumulation and metabolism of necrophagic insects as well as drugs and poisons concentrations or their metabolites in insect and human tissues (Introna Jr et al. 1990).

If we knew the different ways by which absorption, bioaccumulation and excretion of substances/drugs take place in fly larvae, this could help us understand some of our contradictory results, for instance the significant difference in the viability of T1 with respect to the control and T2, and the pupal viability of T3 differing from the control.

Few differences were observed after the introduction of the antibiotic ampicillin in the larval diet, therefore its presence in the food source in the concentrations used in this study does not significantly interfere with larval development.

\section{ACKNOWLEDGMENTS}

We thank Conselho Nacional de Desenvolvimento Científico e Tecnológico (CNPq), Financiadora de Estudos e Projetos (FINEP), Universidade Federal do Estado do Rio de Janeiro (UNIRIO) and Fundação Carlos Chagas Filho de Amparo à Pesquisa do Estado do Rio de Janeiro (FAPERJ) for the financial support for this work.

\section{RESUMO}

Nós avaliamos aqui os efeitos de diferentes concentrações do antibiótico ampicilina sobre o crescimento e desenvolvimento de Chrysomya putoria. Larvas de primeiro instar (L1), de terceira geração, criadas em 60 gramas de homogenato de moela em agar $65 \%$ foram tratadas com ampicilina sódica. $\mathrm{O}$ experimento consistiu de quatro repetições (40 larvas / réplicas) para cada concentração do antibiótico testado (T1: $66 \mu \mathrm{g}$ / $\mathrm{mL} ; \mathrm{T} 2: 81,33 \mu \mathrm{g} / \mathrm{mL}$ e $\mathrm{T} 3: 166,66 \mu \mathrm{g} / \mathrm{mL})$ e о $\mathrm{T} 4:$ controle. A massa corporal das larvas maduras, após abandonarem a dieta, foi registrada em lotes de cinco. A variação entre a massa corporal média de larvas e a duração das taxas de desenvolvimento de larva, pupa e a duração total do desenvolvimento, viabilidades e taxas de normalidade foram analisadas por ANOVA. Não houve diferença significativa entre os quatro tratamentos nos seguintes parâmetros: massa corporal de larvas que abandonaram a dieta, bem como, a duração larval, pupal e desenvolvimento total. As proporções sexuais encontradas nos quatro tratamentos não diferiram do esperado. Taxas de normalidade foram de 100\% para todos tratamentos. Não houve diferença significativa entre os tratamentos para as viabilidade larval e total, mas a viabilidade de pupa diferiu significativamente entre T1 e o controle, T1 e T2, e entre o controle e T3. $\mathrm{O}$ antibiótico pareceu não alterar significativamente o desenvolvimento de C. putoria.

Palavras-chave: Ampicilina, biologia, moscas varejeiras, Calliphoridae, entomologia forense.

\section{REFERENCES}

Aguiar-COElho VM AND Milward-DE-AZEVEdo EMV. 1996. Relações intra-específicas de Cochliomyia macellaria (Fabricius) e Chrysomya albiceps (Wiedemann), Chrysomya megacephala (Fabricius) e Cochliomyia macellaria (Fabricius) (Calliphoridae, Diptera) sob condições de laboratório. Rev Bras Entomol 41: 35-40.

BARBosa LS, JESUS DML AND AgUIAR-COELHO VM. 2004. Longevidade e capacidade reprodutiva de casais agrupados de Chrysomya megacephala (Fabricius, 1794) (Diptera: Calliphoridae) oriundos de larvas criadas em dieta natural e oligídica. Rev Bras Zoociências 6: 207-217.

BATISTA-DA-SILVA JA, MOYA-BORJA GE AND QUEIROZ MMC. 2010. Ocorrência e Sazonalidade de Muscóides (Diptera,Calliphoridae) de Importância Sanitária no 
Município de Itaboraí, RJ, Brasil. Entomo Brasilis 3(1): 16-21.

BRAGA LBF, THOMPSON NR, GADELHA BQ, VELOSO ARA, HOERLLE MO, AGUIAR-COELHO VM AND LESSA CSS. 2011. Miíase associada a erisipela bolhosa. Rev Patol Trop 40(3): 271-276.

Bubli OA, ImASHeVA AG AND LOESCHCKe V. 1998. Selection for knockdown resistance to heat in Drosophila melanogaster at high and low larval densities. Evolution 52: 619-625.

CABRINI I, GRELla MD, ANDRADE CFS AND THYSSEN PJ. 2013. Richness and composition of Calliphoridae in an Atlantic Forest fragment: implication for the use of dipteran species as bioindicators. Biodivers Conserv 22: 2635-2643.

CARVAlHO LM, LINHARES AX AND BADAN-PALHARES FA. 2012. The effect of cocaine on the development rate of immatures and adults of Chrysomya albiceps and Chrysomya putoria (Diptera: Calliphoridae) and its importance to postmortem interval estimate. Forensic Sci Int 220: 27-32.

CARVAlHo LM, Linhares AX AND TRIGO JR. 2001. Determination of drug levels and the effect of diazepam on the growth of necrophagous flies of forensic importance in southeastern Brazil. Forensic Sci Int 120(1-2):140-144.

CARVAlho LML, THYSSEN PJ, GOFF ML AND LiNHARES AX. 2004. Observations on the succession patterns of necrophagous insects onto a pig carcass in an urban area of Southeastern Brazil. Anil Aggrawal's Internet J Forensic Med 5(1): 33-39.

Dallavecchia DL, Proenca BN AND COElHo VMA. 2011. Bioterapia: uma alternativa eficiente para o tratamento de lesoes cutaneas. R. Pesq.: Cuid Fundam Online 3(3): 2071-2079.

Dallavecchia DL, Silva-Filho RG AND Aguiar VM. 2014. Sterilization of Chrysomya putoria (Insecta: Diptera: Calliphoridae) eggs for use in biotherapy. J Insect Sci 14(160).

EL-BAR MM AND SAWABY RF. 2011. A preliminary investigation of insect colonization and succession on remains of rabbits treated with an organophosphate insecticide in el-qalyubiya governorate of egypt. Forensic Sci Int 208(1-3): 26-30.

FARIA LDB, GODOY WAC AND REIS SF. 2004. Larval predation on different instars in blowfly populations. Brazil Arch Biol Technol 47: 887-894.

FERraZ ACP, ALMEIDA VRG, Jesus DM, NunEs RV, NASCIMENTO BP, COELHO VMA AND LESSA CSS. 2011b. Epidemiological Study of Myiases in Hospital do Andarai, Rio de Janeiro, with the Occurrence of an Exotic Etiological Agent. Neotrop Entomol 40: 393-397.

FERrAZ ACP, Bosisio DD AND AGUIAR-COELHO VM. 2011a. Dieta para larvas de Chrysomya megacephala,
Chrysomya putoria e Cochliomyia macellaria (Diptera: Calliphoridae). Entomo Brasilis 4(3): 125-129.

FERRAZ ACP, DALLAVECCHIA DL, SILVA DC, CARVALHO RP, SILVA-FILHO RG AND AGUIAR-COELHO VM. 2012. Alternative diets for Chrysomya putoria, an Old World screwworm fly. J Insect Sci 12: 43.

FERRAZ ACP, GADELHA BQ AND AGUIAR-COELHO VM. 2009. Análise faunística de Calliphoridae (Diptera) da Reserva Biológica do Tinguá, Nova Iguacu, Rio de Janeiro. Rev Bras Entomol 53: 620-628.

FURLANETTO SMP, CAMPOS MLC, HARSI CM, BURALLI GM AND IshIHATA GK. 1984. Microrganismos enteropatogênicos em moscas africanas pertencentes ao gênero Chrysomya (Diptera, Calliphoridae) no Brasil. Rev Microbiol 15: 170-174.

GeOrge KA, ARCHER MS, GREEN LM, CONLAN XA AND TOOP T. 2009. Effect of morphine on the growth rate of Calliphora stygia (Fabricius) (Diptera: Calliphoridae) and possible implications for forensic entomology. Forensic Sci Int 193: 21-25.

GOFF ML, BROWN WA, HEWADIKARAM KA AND OMORI AI. 1991. Effect of heroin in decomposing tissues on the development rate of Boettcherisca peregrina (Diptera, Sarcophagidae) and implications of this effect on estimation of postmortem intervals using arthropod development patterns. J Forensic Sci 36(2): 537-542.

GOODBROD JR AND GOFF ML. 1990. Effects of larval population density on rates of development and interactions between two species of Chrysomya (Diptera: Calliphoridae) in laboratory culture. J Med Entomol 27: 338-343.

Gosselin M, Di FAZIO V, WILlE SM, FERNANDEZ MM, SAMYN N, BOUREL B AND RASMONT P. 2011. Methadone determination in puparia and its effect on the development of Lucilia sericata (Diptera, Calliphoridae). Forensic Sci Int 209: 154-159.

GREENBERG B. 1990. Behavior of postfeeding larvae of some Calliphoridae and a muscid (Diptera). Ann Ent Soc Am 83: $1210-1214$.

Grella MD, Estrada DA AND THYSSEN PJ. 2007. Scopolamine effect on the development of Chrysomya putoria (Wiedemann) (Diptera: Calliphoridae) and its importance for the post mortem interval estimate. Entomol Mexic 6: 870-873.

GUIMARÃES JH AND PAPAVERO N. 1999 Myiasis in man and animals in the Neotropical Region: bibliographic database. São Paulo, FAPESP, 308 p.

HÉdouin V, BOUREL B, MARTIN-BOUVER L, BECART A, Tournel G, Deveaux M And Gosset. 1999. Determinations of drug levels in larvae of Lucilia sericata reared on rabbit carcasses containing morphine. J For Sci 44: 351-353.

INTRONA F, CAMPOBASSO CP AND GOFF ML. 2001. Entomotoxicology. Forensic Sci Int 120: 42-47. 
INTRONA JR F, LO-DICO C, CAPLAN YH AND SMIALEK JE. 1990. Opiate analysis of cadaveric blowfly larvae as an indicator of narcotic intoxication. J For Sci 35: 118-122.

KHAZAELI AA, FUKVI HH AND CURTSINGER JW. 1993. Egg and larval densities and survival rates in an inbred line of Drosophila melanogaster. Drosoph Inf Serv 72: 142-143.

KINTZ P, TRACQUi A, LUDES B, WALLER J, BOUKHABZA A, MANGIN P, LUGNIER AA AND CHAUMONT AJ. 1990. Fly larvae and their relevance in forensic toxicology. AJFMP 11: 63-65.

Kosmann C, Mello RP, HARTERREITEN-SOUZA ES AND PUJOL-LUZ JR. 2013. A List of Current Valid Blow Fly Names (Diptera: Calliphoridae) in the Americas South of Mexico with Key to the Brazilian Species. Entomo Brasilis 6(1): 74-85.

LIU X, SHI Y, WANG H AND ZHANG R. 2009. Determination of Malathion levels and its effect on the development of Chrysomya megacephala (Fabricius) in South China. Forensic Sci Int 193: 26-36.

LOUREIRO MS, OLIVEIRA VC AND D'ALMEIDA JM. 2005. Desenvolvimento posembrionario de Pattonella intermutans (Thomson) (Diptera: Sarcophagidae) em diferentes dietas. Rev Bras Entomol 49: 127-129.

MELLO RP. 2003. Chave para identificação das formas adultas da espécies da família Calliphoridae (Diptera: Brachycera, Cyclorrhapha) encontradas no Brasil. Entomol Vectores 10(2): 255-268.

MEllo RS, Queiroz MMC AND AguiAR-CoElho VM. 2007. Population fluctuations of calliphorids species (Diptera, Calliphoridae) in the Biological Reserve of Tinguá, state of Rio de Janeiro, Brazil. Iheringia - Serie Zoologica 97(4): 1-5.

MestanZA F AND PAMO O. 1992. Estudio muestral del consumo de medicamentos y automedicacion en Lima Metropolitana. RMH 3: 101-108.

O'BRIEN C AND TURNER B. 2004. Impact of paracetamol on Calliphora vicina larval development. Int J Legal Med 118(4): 188-189.

Oliveira MS, Mello RP AND Queiroz MMC. 2007. Morfologia e duração dos ínstares larvais de Chrysomya putoria (Wiedemann) (Diptera, Calliphoridae), em laboratório. Rev Bras Entomol 51(2): 239-245.

OLIVEIRA TC AND VASCONCELOS SD. 2010. Insects (Diptera) associated with cadavers at the Institute of Legal Medicine in Pernambuco, Brazil: Implications for forensic entomology. Forensic Sci Int 198: 97-102

OLIVEIRA-COSTA J. 2011. Entomologia forense: Quando os insetos são vestígios. Millennium. Campinas, Brasil, 520 p.

PARRA JRP. 2002. Controle biológico no Brasil: Parasitóide e Predadores. Manole Ltda. Barueri, Brasil, 609 p.
PARRY S, LINTON SM, FRANCIS PS, O'DONNELL MJ AND TOOP T. 2011. Accumulation and excretion of morphine by Calliphora Stygia, an Australian blow fly species of forensic importance. J Insect Physiol 57(1): 62-73.

PORTO CC. 2012. Vademecum de Clinica Médica, Guanabara Koogan, Rio de Janeiro, Brasil, 1192 p.

REIS SF, STANGENHAUS G, GODOY WAC, VON ZUBEN CJ AND RIBEIRO OB. 1994. Variação em caracteres binômicos em função de densidade larval em Chrysomya megacephala e Chrysomya putoria (Diptera, Calliphoridae). Rev Bras Entomol 38: 33-46.

RIBEIRO OB. 1998. Dynamics of equilibrium in experimental populations of Cochliomyia macellaria (Diptera: Calliphoridae). Rev Bras Entomol 42: 43-51.

Ribeiro OB, Prado AP AND GUIMARÃES JH. 1993. Competição intraespecífica em Chrysomya putoria (Wiedemann, 1983) (Diptera, Calliphoridae) em meio artificial. Rev Bras Entomol 37: 641-652.

Roper C, PIGNATELli P AND PARTRIDGE L. 1996. Evolutionary responses of Drosophila melanogaster life history to differences in larval density. J Evol Biol 9: 609-622.

SADLER DW, RICHARDSON J, HAIGH S, BRUCE G AND POUNDER DJ. 1997: Amitriptyline accumulation and elimination in Calliphora vicina larvae. Am J Forensic Med Pathol 18: 397-403.

SoTO D. 2008. Avaliação da taxa de desenvolvimento de três espécies de califorídeos (Diptera) de importância forense sob o efeito de dois barbitúricos. Thesis $\mathrm{PhD}$, Universidade Estadual de Campinas, SP, Brasil.

TAVARES W. 2014. Antibióticos e Quimioterápicos para o clinico: Edição Revista e Atualizada, Atheneu Rio, Brasil, $712 \mathrm{p}$.

THYSSEN PJ AND GRELLA MD. 2011. Efeito da escopolamina sobre o desenvolvimento de Chrysomya putoria (Diptera: Calliphoridae) e sua importância para a estimativa do intervalo pos-morte. RBC 1(1): 39-42.

UNODC - UNITED NATIONS OFFICE ON DRUGS AND CRIME. 2007. World drug report. United Nations: Office on drugs and crime. Available: http://www.unodc.org/brazil/pt/ pressrelease_20072506.html).

VANLAERHOVEN SL. 2008. Blind validation of postmortem interval estimates using developmental rates of blow flies. Forensic Sci Int 180(2-3): 76-80.

WANNMACHER L. 2004. Uso indiscriminado de antibióticos e resistência microbiana: Uma guerra perdida? Uso racional de medicamentos: Temas selecionados. Porto Alegre, Brasil: Horus, p. 1-6.

YAGHOOBI R, TIRGARI S AND SinA N. 2005. Human auricular myiasis caused by Lucilia sericata: clinical and parasitological considerations. Acta Med Iranica 43: 155157. 